Sains Malaysiana 50(2)(2021): 429-436

http://dx.doi.org/10.17576/jsm-2021-5002-14

\title{
Effect of the Tocotrienol-Rich Fraction (TRF) on the Healthspan of Caenorhabditis elegans
}

(Kesan Fraksi Kaya Tokotrienol (TRF) pada Jangka Kesihatan Caenorhabditis elegans)

\author{
Tan Tzer Sien, Muhammad Firdaus Sathik Rahman, Siti Sara Ismail, Nur Najihah Mohamad, Ahmad \\ Hazim Mustaffa, Geetha Gunasekaran, Siti Bazilah Zulkefli \& Goon Jo Aan*
}

\begin{abstract}
Vitamin $E$ is an established antioxidant. However, the effect of vitamin $E$ on healthspan, which deteriorates during ageing, has not been determined because most related studies have emphasized its effects on lifespan. Therefore, the purpose of this study was to determine the effect of palm tocotrienol-rich fraction (TRF) on the lifespan, locomotion and thermotolerance of Caenorhabditis elegans, which share many common gene sequences with humans. The nematodes were treated with different concentrations of TRF $(0-200 \mu \mathrm{g} / \mathrm{mL})$, and the number of surviving nematodes at each concentration $(N=30$, duplicate) was counted daily under a light microscope to determine the optimal dose of treatment. The nematodes were divided into 3 groups, namely; control, Tween-80 (vehicle) and TRF-treated. Locomotion and thermotolerance were determined on day 4 and 12 of treatment in adult nematodes. ImageJ was used for locomotion analysis, and thermotolerance was determined based on nematode survivals after exposure to $37{ }^{\circ} \mathrm{C}$. TRF-treated $\mathrm{C}$. elegans had significantly longer lifespans compared to controls $(P=0.003)$. The TRF group $(50 \mu \mathrm{g} / \mathrm{mL})$ had the longest mean lifespan (23.5 days), which was significantly longer compared to controls, (18.5 days; $(P=0.002)$. However, locomotion was similar between all groups. In the thermotolerance assay, the survival determined on day 4 and day 12 of TRF-treatment was higher compared to controls $(P=0.046)$. Interestingly, the Tween-80-treated group showed similar results as the TRF-treated group compared to controls. The findings indicate that TRF prolongs the lifespan and increases the thermotolerance of $\mathrm{C}$. elegans but does not improve the locomotion of the worms as they age.
\end{abstract}

Keywords: Ageing; locomotion; oxidative stress; thermotolerance; vitamin E

\section{ABSTRAK}

Vitamin E adalah antioksidan yang diperakui tetapi kesannya terhadap jangka kesihatan yang kian merosot seiring dengan proses penuaan masih kurang jelas. Tujuan kajian ini adalah untuk menentukan kesan fraksi kaya tokotrienol (TRF) pada jangka hayat, pergerakan dan termotoleransi menggunakan Caenorhabditis elegans, yang berkongsi banyak urutan gen biasa dengan manusia. Nematoda dirawat dengan kepekatan TRF yang berbeza $(0-200 \mu \mathrm{g} / \mathrm{mL})$ dan jumlah nematoda yang masih hidup pada setiap kepekatan $(N=30$, duplikat) dihitung setiap hari di bawah mikroskop untuk menentukan dos rawatan optimum. Nematoda dibahagikan kepada 3 kumpulan iaitu; kawalan, Tween-80 (pengangkut) dan TRF. Pengasaian pergerakan dan termotoleransi ditentukan pada hari ke-4 dan ke-12 kedewasaan nematoda. ImageJ digunakan untuk analisis pengasaian pergerakan dan pengasaian termotoleransi ditentukan melalui kemandirian nematoda selepas pendedahan kepada $37^{\circ} \mathrm{C}$. C. elegans yang dirawat dengan TRF mempunyai jangka hayat yang jauh lebih panjang berbanding dengan kawalan $(P=0.003)$. Kumpulan TRF $(50 \mu \mathrm{g} / \mathrm{mL})$ mempunyai jangka hayat purata tertinggi iaitu (23.5 hari), berbanding dengan kawalan, (18.5 hari; $(P=0.002)$. Bagaimanapun, kebolehan lokomotif adalah sama antara semua kumpulan. Dalam ujian termotoleransi, ketahanan suhu bagi nematoda hari ke-4 dan hari ke12 nematoda yang dirawat TRF lebih tinggi berbanding dengan kawalan $(P=0.046)$. Menariknya, kumpulan Tween-80 juga menunjukkan keputusan yang sama seperti TRF apabila dibandingkan dengan kawalan. TRF memanjangkan jangka hayat dan meningkatkan termotoleransi C. elegans tanpa meningkatkan pergerakan nematoda semasa mereka berumur.

Kata kunci: Pengasaian pergerakan; penuaan; tekanan oksidatif; tekanan suhu; vitamin E 


\section{INTRODUCTION}

Since the last century, humans have increasingly investigated ways to extend the lifespan (Crimmins 2015). Many methods have been utilized to achieve this objective. However, a longer lifespan alone is no longer the ultimate goal. In recent decades, research has also focused on therapeutic approaches that can extend the healthspan as well (Crimmins 2015; Olshansky 2018). This research is carried out with the understanding that the human lifespan and healthspan are affected by the ageing process. According to Harman (1981), ageing is the progressive accumulation of changes over time that are associated with or responsible for the ever-increasing susceptibility to disease and death that accompanies advancing age. One established theory states that ageing is largely a product of the accumulation of free radicals (Beckman \& Ames 1998; Brintz 2013).

With the objective of extending both lifespan and healthspan, many animal models have been introduced as substitutes for human (Mitchell et al. 2015). One of these models is the free-living nematode Caenorhabditis elegans. C. elegans is well-suited to studies of ageing owing to its simple developmental process, wellcharacterized genome (which has $60-80 \%$ similarity with humans), ease of maintenance, short and prolific life cycle, and a small body size (Goon et al. 2019; Leung et al. 2008).

To overcome the detrimental effects of free radicals, many antioxidant compounds have been studied, including vitamin E (Frei 2012). Vitamin E is considered to be the most established lipid-soluble antioxidant and comprises eight isomers, including: $\alpha-, \beta-, \gamma$ - and $\delta$-tocopherol and tocotrienol (Sen et al. 2010). Recent studies have documented that tocotrienol is a more potent antioxidant than tocopherol (Goon et al. 2019; Ng et al. 2004; Sen et al. 2004). Palm oil is rich in tocotrienol; approximately $75 \%$ of the total vitamin $\mathrm{E}$ is present as tocotrienols in palm oil (Ramanathan et al. 2018; Sen et al. 2006).

Tocopherols have been investigated in many studies, but tocotrienols have not, due to their quantitative differentiation in vivo. Thus, the role of tocotrienols in healthspan has not been fully clarified to date. Studies of tocotrienol have shown that activation of lipopolysaccharide-induced nuclear factor $\kappa B(\mathrm{Z}-\kappa B)$ is significantly inhibited in various cancer cell lines (Nesaretnam \& Meganathan 2011). Previous studies have determined the effects of tocotrienols on the accumulation of lipofuscin (Goon et al. 2013) and protein carbonylation (Adachi \& Ishii 2000) in C. elegans, in addition to its effect on lengthening the lifespan. Previous studies have also identified the effects of tocotrieonols as antioxidants on other organisms. Among these effects are anti-inflammatory and antioxidative properties in combating ulcerative colitis in mice (Saw et al. 2019) and the inhibition of cytotoxicity in an in vitro model of Alzheimer's disease (Gugliandolo et al. 2019).

One recent study showed that tocotrienol helps in wound healing by reducing nitrite production and lipid peroxidation in the skin of rats with deep partialthickness burns (Guo et al. 2020). In vivo studies using tocotrienol showed that bone mineralization is enhanced through promoting osteoblast differentiation, and suppressing osteoclast formation and differentiation by lowering lipid peroxidation, inflammation, and glucose homeostasis regulation (Meister et al. 2020; Shen et al. 2018). Tocotrienol also has the ability to cross the bloodretinal barrier (BRB) and inhibit retina degeneration in rats when given as an oral supplement (Sadikan et al. 2020).

In this study, we aimed to identify the effects of TRF on the healthspan and lifespan of C. elegans. The healthspan of $C$. elegans was investigated based on the locomotion and thermotolerance of the organisms. The information obtained from this study will further clarify the role of tocotrienol in the prevention of ageing.

\section{MATERIALS AND METHODS}

\section{NEMATODE STRAIN AND CULTURE CONDITIONS}

Wild-type $C$. elegans strain (N2) used in this study was obtained from the Universiti Kebangsaan Malaysia Molecular Biology Institute (UMBI). All the nematode maintenance and handling procedures were conducted as described in Brenner's studies (Brenner 1974). The nematodes were maintained at $20^{\circ} \mathrm{C}$ on nematode growth media with $E$. coli OP50 as a food source (Stiernagle 2006). To prevent the production of progeny, the nematodes were transferred to plates containing $40 \mu \mathrm{M} 5$-fluoro2'-deoxyuridine (FUdR; Sigma-Aldrich, St. Louis, MO, USA) once they reached the L4 stage. Age-synchronized nematodes (L4 stage) were used in all lifespan and healthspan assays. All assays were performed in duplicate with 10 nematodes per plate $(\mathrm{N}=10)$.

The optimal dose of TRF treatment was determined by treating the nematodes with $10-200 \mu \mathrm{g} / \mathrm{mL} \mathrm{TRF}$, and the maximum lifespan was determined. For the healthspan analysis, nematodes were divided into 3 groups; control, Tween-80, and TRF. The TRF treatments were administered from day 1 of L4 until days 4 and 12 .

\section{NEMATODE GROWTH MEDIUM (NGM) WITH TRF INFUSION}

TRF was supplied by Davos Life Science Sdn. Bhd. (Selangor, Malaysia), commercially known as DavosLife E3 DVL 95, which consists of $65.0 \%$ tocotrienol (24.4\% 
$\alpha$-tocotrienol, 2.1\% $\beta$-tocotrienol, 29.0\% $\gamma$-tocotrienol and $9.5 \% \delta$-tocotrienol), $28.2 \% \alpha$-tocopherol, and $4.4 \%$ $\alpha$-tocomonoenol with $95 \%$ vitamin E purity. The optimal dose of TRF for the treatment of C. elegans, $50 \mu \mathrm{g} /$ $\mathrm{mL}$, was ascertained based on the highest survival rate of nematode after exposure to various concentrations of TRF (Table 1). NGM containing $50 \mu \mathrm{g} / \mathrm{mL}$ TRF was then prepared according to a previous study with slight modifications (Adachi \& Ishii 2000). Briefly, $0.882 \mathrm{~g}$ of TRF was dissolved in $5 \mathrm{~mL}$ of absolute ethanol containing $0.882 \mathrm{~g}$ of Tween- 80 . Next, $1 \mathrm{~mL}$ of the diluted TRF was mixed with $1 \mathrm{~mL}$ of Milli-Q water, followed by sonication. A total of $0.0125 \mathrm{~mL}$ of TRF solution was then added aseptically to $12.5 \mathrm{~mL}$ of autoclaved nematode growth media (NGM), and the mixture was solidified in Petri dishes (Goon et al. 2013).

\section{LIFESPAN STUDY OF C. elegans}

The lifespan study was conducted based on the methods of a previous investigation (Huang et al. 2004). Two agar plates (duplicate) containing 30 nematodes each were prepared for each treatment group (control, 10, 25, 50, 100 , and $200 \mu \mathrm{g} / \mathrm{mL}$ TRF) and assayed simultaneously. The number of surviving nematodes was counted daily under light microscope. Nematodes that failed to respond or move after 3 probing attempts using a platinum wire were determined to be dead.

\section{LOCOMOTION}

On day 4 and day 12 of treatment, the nematodes were visualized using light microscope. Locomotion was determined by measuring the total distance travelled by the worm in 30 seconds in an empty plate seeded with OP50 (Fang et al. 2017). The distance was measured from head start to head end using ImageJ. The mean distance travelled by each group was then compared.

\section{THERMOTOLERANCE}

On day 4 and day 12 of treatment, the nematodes were exposed to $37^{\circ} \mathrm{C}$ heat stress (Fang et al. 2017), and the number of surviving nematodes were counted every hour under a light microscope until all the nematodes were dead (Keith et al. 2014). Nematodes that failed to respond or move after 3 probing attempts using a platinum wire were determined to be dead.

\section{STATISTICAL ANALYSIS}

The lifespan assay results were analysed using one-way analysis of variance (ANOVA) and Tukey's post hoc test. Repeated measures ANOVA and Tukey's post hoc test was used to analyse the healthspan parameters. The differences were considered to be significant at $p<0.005$. The statistical analysis was conducted using SPSS version 22.0 (SPSS, Inc., Chicago, IL, USA). The results are shown as the mean $\pm \mathrm{SD}$

\section{RESULTS AND DISCUSSION}

\section{LIFESPAN STUDY}

C. elegans has been widely used as a model organism in ageing studies because of its biological information, which may be directly applicable to humans. The optimal dose of TRF treatment was determined based on the highest survival rate of nematodes after exposure to $10-200 \mu \mathrm{g} /$ $\mathrm{mL}$ TRF. Previous studies have shown that extremely high concentrations of TRF reduce nematode survival to that of controls (Adachi \& Ishii 2000; Goon et al. 2013). Hence, to determine how TRF affects the nematodes in terms of healthspan, the maximal survival rate was used. In the present study, the TRF-treated $C$. elegans were found to have a significantly longer lifespan $(p<0.05)$ compared to the control group (Figure 1), with $50 \mu \mathrm{g} / \mathrm{mL}$ TRF giving the longest mean lifespan (23.5 days). This lifespan was, longer than the lifespan of the control group by 5 days (Table 1).

The $50 \mu \mathrm{g} / \mathrm{mL}$ TRF concentration was found to be the optimum concentration for increasing the mean lifespan of C. elegans; this finding was in line with a previous study (Goon et al. 2013). Hence, for further experiments, $50 \mu \mathrm{g} /$ $\mathrm{mL}$ TRF was chosen as the optimal dose.

A different study also found that the administration of TRF extended the mean lifespan of $C$. elegans but at a higher concentration, $80 \mu \mathrm{g} / \mathrm{mL}$ (Adachi \& Ishii 2000). The administration of TRF extended the mean lifespan of $C$. elegans by preventing protein oxidation under physiological conditions (Adachi \& Ishii 2000). TRF has also been found to modulate the expression of genes in the insulin/IGF-1 signalling pathway, which is involved in the regulation of lifespan in C. elegans (Goon et al. 2013).

\section{LOCOMOTION ASSAY}

Lifespan is an overall measure of the function of a lifesupport system. In this study, locomotion (physiological function) and thermotolerance (physiological stress response) were used as parameters to assess the health status. Upon ageing, C. elegans show a locomotory decline as a consequence of age-related muscle deterioration, also known as sarcopenia (Herndon et al. 2002). In the current study, the mean distance travelled by $C$. elegans declined from day 4 of adulthood to day 12 in all groups. This could be due to the weakness of the nematodes' muscles and a general decline in cellular integrity as the worms aged (Glenn et al. 2004). Treatment with TRF did not slow this 
decline (Table 2(b)). TRF treatment apparently improved the overall locomotion of $C$. elegans on day 4 and day 12 compared to the control group (Table 2(a)). However, the improvement was not significant. Unfortunately, TRF treatment did not help in slowing the ageing effect, because no significant differences were observed between the TRFtreated group and the control.

While no comparable studies have measured locomotion in TRF-treated C. elegans, A $\beta \mathrm{PP} / \mathrm{PS} 1$ mice that were administered long-term (10 months) TRF treatment $(60 \mathrm{mg} / \mathrm{kg})$ showed a significant increase in total rearing time. However, the total number of movements, total path length travelled, and the number of line crossings showed no significant difference among groups (Durani et al. 2018). In another study, functional recovery following spinal cord injury (SCI) was measured in mice by using the Basso Beattie Bresnahan (BBB) locomotor rating scale. At one day post-SCI, the BBB scores were not significantly different in the tocotrienol groups compared to the SCI group. However, at eight weeks post-SCI, the BBB scores were significantly higher in the tocotrienol groups compared with the SCI group (Xun et al. 2017). Thus, we hypothesized that a longer duration of TRF treatment may be needed to produce a significant result in the locomotion study.

\section{THERMOTOLERANCE ASSAY}

In the thermotolerance assay, the survival time of TRFtreated C. elegans' was significantly longer compared to the control group (Table 3(a) \& 3(b)). According to Butt et al. (2017), vitamin E preconditioning of human skin fibroblasts successfully counteracted heat stress in vitro by stimulating the synthesis of polypeptides, such as heat shock proteins (HSPs). It is believed that these stress proteins are essential for survival at increased temperatures and play a role in the development of thermotolerance and protection from cellular damage (Kregel 2002). In line with this hypothesis, Kregel (2002) also suggested that ageing reduces tolerance to thermal stress by lowering the concentration of HSPs, which are responsible for the refolding of misfolded peptides and prevent protein aggregation (Anckar \& Sistonen 2011).
Interestingly, Tween-80 also improved the thermotolerance of $C$. elegans compared to the control (Figures $2 \& 3$ ). Treatment with the vehicle resulted in the longest mean survival among all groups on both day 4 $(9.0 \pm 0.289 \mathrm{~h})$ and day $12(8.0 \pm 0.645 \mathrm{~h})$. This is probably because Tween- 80 affects nutrition bioavailability by protecting against adverse environmental conditions, including acidity (Broadbent et al. 2014). Furthermore, the oleic acid moiety of Tween- 80 can be incorporated into the cell membrane, thereby affecting cell membrane properties (Reitermayer et al. 2018). However, the exact physiological mechanism underlying the growth enhancement and stress protection conferred by Tween-80 is not completely clear.

In one previous study, male Wistar rats (young: 3 -months old; aged: 21 months old) were used as an ageing model, and TRF supplementation was found to reverse age-related behavioural impairments. However, TRF did not significantly affect the behavioural patterns of young rats. TRF supplementation in aged rats also decreased the amount of DNA damage and MDA (a biomarker of lipid peroxidation) levels. However, the MDA levels in young rats supplemented with TRF remained unchanged compared to their age-matched controls (Sadikan et al. 2020). Thus, the study demonstrated that TRF treatment was more effective in improving health in aged animals. Older worms may be more responsive to TRF treatment than younger worms due to the presence of higher levels of oxidative stress.

One of the limitations of the current study was that day 12 nematodes may not be old enough to exhibit positive effects of TRF treatment. Our study was designed based on a previous investigation of C. elegans locomotion and thermotolerance carried out by Fang et al. (2017). They designated day 4 as young worms and day 12 as aged worms. Normal, untreated worms are believed to have a 21 day of life cycle. However, some previous studies have suggested that day 12 of the L4 stage is the age at which age-dependent changes begin to take place at the tissue and cellular levels. Therefore, day 12 worms may not be old enough to be considered as aged worms.

TABLE 1. Mean lifespan of C. elegans exposed to different concentrations of TRF compared to controls

\begin{tabular}{cccc}
\hline Group & & Mean lifespan (days) $\pm \mathrm{SD}$ & p-value \\
\hline Control & & $18.5 \pm 0.71$ & - \\
\hline $\operatorname{TRF}(\mu \mathrm{g} / \mathrm{mL})$ & 10 & $21.5 \pm 0.71$ & 0.025 \\
& 25 & $21.5 \pm 0.71$ & 0.025 \\
& 50 & $23.5 \pm 0.71$ & 0.002 \\
& 100 & $22.5 \pm 0.71$ & 0.006 \\
& 200 & $22.0 \pm 0.71$ & 0.012 \\
\hline
\end{tabular}


TABLE 2. a. Mean distance travelled by C. elegans on day 4 and day 12 of treatment. b. Percentage of decrease in distance travelled

a.

\begin{tabular}{ccc}
\hline & Group & Mean distance $(\mathrm{mm}) \pm \mathrm{SD}$ \\
\hline Day 4 & Control & $7.05 \pm 0.25$ \\
& Tween-80 & $6.96 \pm 0.55$ \\
& TRF & $8.29 \pm 0.66$ \\
\hline Day 12 & Control & $3.56 \pm 0.61$ \\
& Tween-80 & $3.1 \pm 0.12$ \\
& TRF & $3.67 \pm 0.2$
\end{tabular}

b.

\begin{tabular}{ccc} 
Group & $\begin{array}{c}\text { Distance } \\
{[(\text { Day 4) }-(\text { Day 12) }) \mathrm{mm}}\end{array}$ & $\begin{array}{c}\text { Percentage of decrease } \\
(\%)\end{array}$ \\
\hline Control & 3.49 & 49.48 \\
Tween-80 & 3.86 & 55.41 \\
TRF & 4.62 & 55.63 \\
\hline
\end{tabular}

TABLE 3. a. Mean survival time of worms from each group. * indicates $p<0.05$. b. Mean survival time of worms from each group. $*$ indicates $\mathrm{p}<0.05$

a.

\begin{tabular}{cc}
\hline Group & Mean survival time $(\mathrm{h}) \pm \mathrm{SD}$ \\
\hline Control & $7.0 \pm 0.29$ \\
Tween-80 & $9.0 \pm 0.29^{*}$ \\
TRF & $8.5 \pm 0.29^{*}$ \\
\hline
\end{tabular}

b.

\begin{tabular}{cc}
\hline Group & Mean survival time (hours) $\pm \mathrm{SD}$ \\
\hline Control & $3.5 \pm 0.65$ \\
Tween-80 & $8.0 \pm 0.65^{*}$ \\
TRF & $7.0 \pm 0.65^{*}$ \\
\hline
\end{tabular}




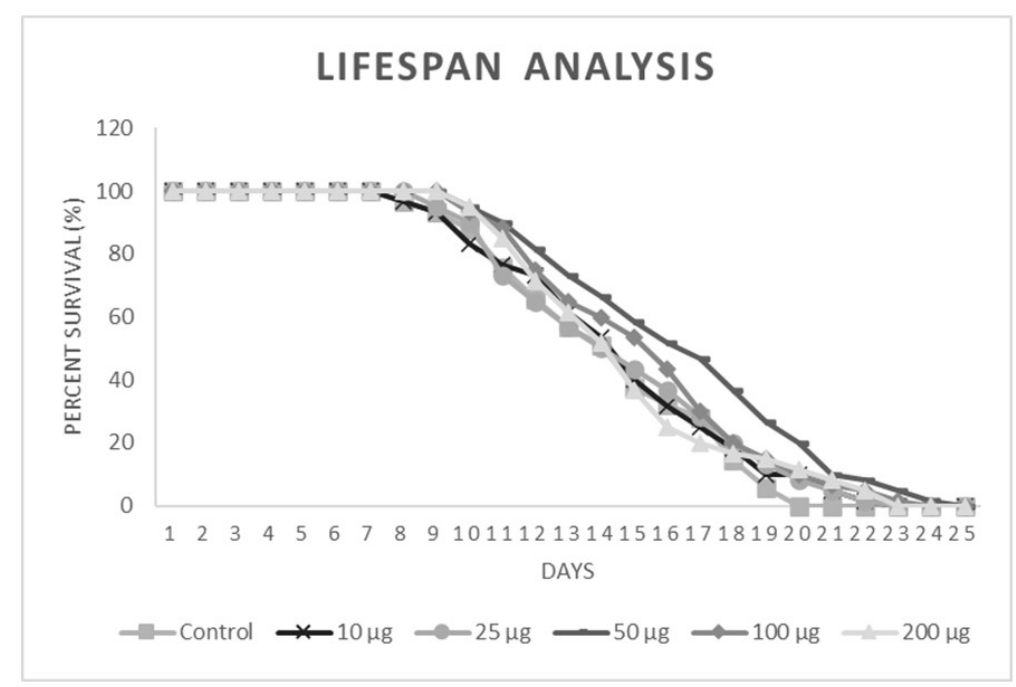

FIGURE 1. Longest mean life span analysis

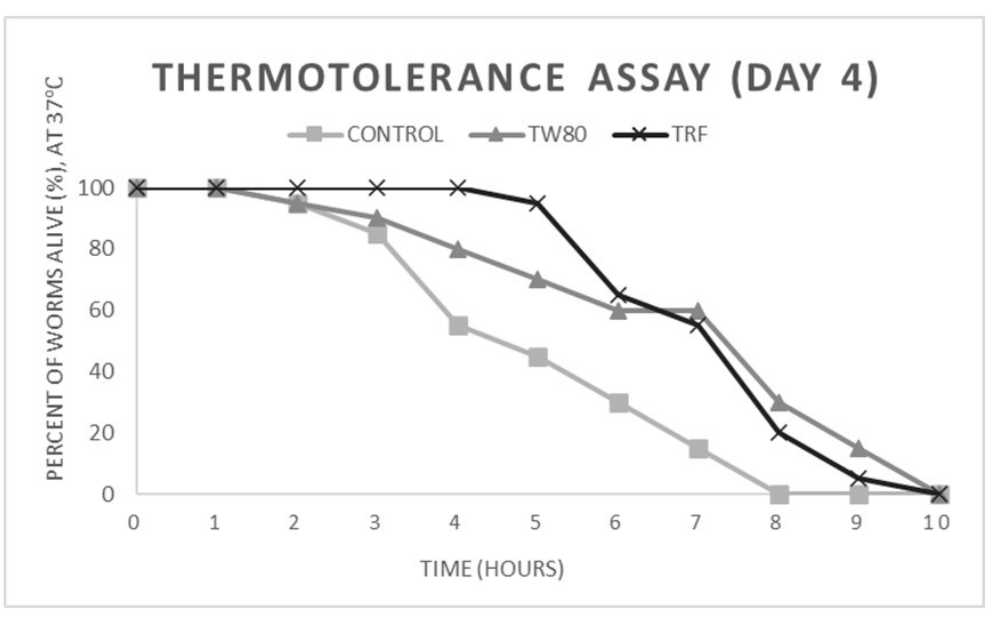

FIGURE 2. Longest mean survival among all group on Day 4

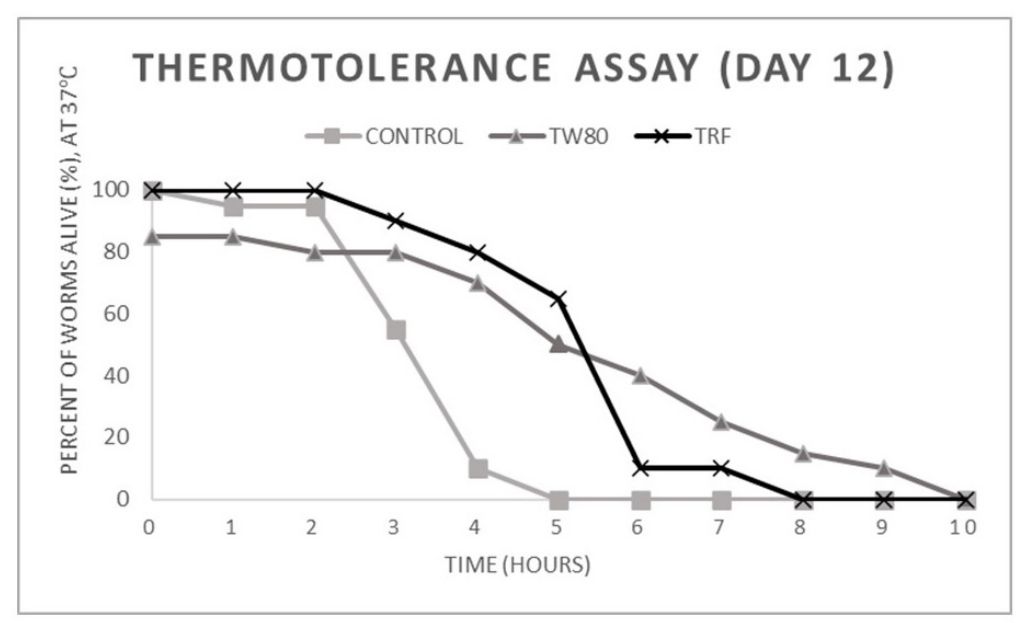

FIGURE 3. Longest mean survival among all group on Day 12 


\section{CONCLUSION}

The application of TRF treatment prolonged lifespan in C. elegans and improved the resistance of the nematodes to heat stress, but it had no effects on locomotion as the nematodes aged.

\section{ACKNOWLEDGEMENTS}

This work was supported by a grant from UKM (FF-2019227) and facilitated by the Department of Biochemistry, Faculty of Medicine, UKM and UKM Molecular Biology Institute, Kuala Lumpur. We thank Davos Life Science Sdn. Bhd. (Selangor, Malaysia) for their contribution of DavosLife E3 Tocotrienol-Rich Fraction for this study.

\section{REFERENCES}

Adachi, H. \& Ishii, N. 2000. Effects of tocotrienols on life span and protein carbonylation in Caenorhabditis elegans. The Journals of Gerontology: Series A 55(6): B280-B285.

Anckar, J. \& Sistonen, L. 2011. Regulation of Hsf1 function in the heat stress response: Implications in aging and disease. Annual Review of Biochemistry 80(1): 1089-1115.

Beckman, K.B. \& Ames, B.N. 1998. The free radical theory of aging matures. Physiological Reviews 78(2): 547-581.

Brenner, S. 1974. The genetics of Caenorhabditis elegans. Genetics 77(1): 71-94.

Brintz, C. 2013. Free-radical theory of aging. In Encyclopedia of Behavioral Medicine, edited by Gellman, M.D. \& Turner, J.R. New York: Springer. https://doi.org/10.1007/978-14419-1005-9 191.

Broadbent, J., Oberg, T.S., Hughes, J.E., Ward, R.E., Brighton, C., Welker, D.L. \& Steele, J.L. 2014. Influence of polysorbate 80 and cyclopropane fatty acid synthase activity on lactic acid production by Lactobacillus casei ATCC 334 at low pH. Journal of Industrial Microbiology \& Biotechnology 41(3): 545-553.

Butt, H., Mehmood, A., Ali, M., Tasneem, S., Anjum, M.S., Tarar, M.N., Khan, S.N. \& Riazuddin, S. 2017. Protective role of vitamin $\mathrm{E}$ preconditioning of human dermal fibroblasts against thermal stress in vitro. Life Sciences 184: 1-9.

Crimmins, E.M. 2015. Lifespan and healthspan: past, present, and promise. Gerontologist 55(6): 901-911.

Durani, L.W., Hamezah, H.S., Ibrahim, N.F., Yanagisawa, D., Nasaruddin, M.L., Mori, M., Azizan, K.A., Damanhuri, H.A., Makpol, S. \& Ngah, W. 2018. Tocotrienol-rich fraction of palm oil improves behavioral impairments and regulates metabolic pathways in A $\beta$ PP/PS1 mice. Journal of Alzheimer's Disease 64(1): 249-267.

Fang, E.F., Waltz, T.B., Kassahun, H., Lu, Q., Kerr, J.S., Morevati, M., Fivenson, E.M., Wollman, B.N., Marosi, K., Wilson, M.A., Iser, W.B., Eckley, D.M., Zhang, Y., Lehrmann, E., Goldberg, I.G., Scheibye-Knudsen, M., Mattson, M.P., Nilsen, H., Bohr, V.A. \& Becker, K.G. 2017. Tomatidine enhances lifespan and healthspan in C. elegans through mitophagy induction via the Skn-1/Nrf2 pathway. Scientific Reports 7: 46208
Frei, B. 2012. Natural Antioxidants in Human Health and Disease. United Kingdom: Academic Press. p. 72.

Glenn, C.F., Chow, D.K., David, L., Cooke, C.A., Gami, M.S., Iser, W.B., Hanselman, K.B., Goldberg, I.G. \& Wolkow, C.A. 2004. Behavioral deficits during early stages of aging in Caenorhabditis elegans result from locomotory deficits possibly linked to muscle frailty. Journals of Gerontology. Series A, Biological Sciences Medical Sciences 59(12): 1251-1260.

Goon Jo Aan, Noralisa Abdul Karim, Mohd Shahril Aszrin Zainudin, Suzana Makpol. 2019. Tocotrienol-rich fraction modulates genes expression in oxidative stress-induced Caenorhabditis elegans. Bangladesh Journal of Medical Science 18(4): 711-721.

Goon Jo Aan, Mohd Shahril Aszrin Zainudin, Noralisa Abdul Karim \& Wan Zurinah Wan Ngah. 2013. Effect of the tocotrienol-rich fraction on the lifespan and oxidative biomarkers in Caenorhabditis elegans under oxidative stress. Clinics 68(5): 599-604.

Gugliandolo, A., Chiricosta, L., Silvestro, S., Bramanti, P. \& Mazzon, E. 2019. $\alpha$-tocopherol modulates nonamyloidogenic pathway and autophagy in an in vitro model of Alzheimer's disease: A transcriptional study. Brain Sciences 9(8): 196.

Guo, H.F., Abd Hamid, R., Mohd Ali, R., Chang, S.K., Rahman, M.H., Zainal, Z. \& Khaza'ai, H. 2020. Healing properties of epidermal growth factor and tocotrienol-rich fraction in deep partial-thickness experimental burn wounds. Antioxidants 9(2): 130.

Harman, D. 1981. The aging process. Proceedings of the National Academy of Sciences 78(11): 7124-7128.

Herndon, L.A., Schmeissner, P.J., Dudaronek, J.M., Brown, P.A., Listner, K.M., Sakano, Y., Paupard, M.C., Hall, D.H. \& Driscoll, M. 2002. Stochastic and genetic factors influence tissue-specific decline in ageing C. elegans. Nature 419(6909): 808-814.

Huang, C., Xiong, C. \& Kornfeld, K. 2004. Measurements of age-related changes of physiological processes that predict lifespan of Caenorhabditis elegans. Proceedings of the National Academy of Sciences 101(21): 8084-8089.

Keith, S.A., Amrit, F.R.G., Ratnappan, R. \& Ghazi, A. 2014. The C. elegans healthspan and stress-resistance assay toolkit. Methods 68(3): 476-486.

Kregel, K.C. 2002. Heat shock proteins: Modifying factors in physiological stress responses and acquired thermotolerance. Journal of Applied Physiology 92(5): 2177-2186

Leung, M.C.K., Williams, P.L., Benedetto, A., Au, C., Helmcke, K.J., Aschner, M. \& Meyer, J.N. 2008. Caenorhabditis elegans: An emerging model in biomedical and environmental toxicology. Toxicological Sciences 106(1): 5-28.

Meister, M.L., Mo, H., Ji, X. \& Shen, C.L. 2020. Tocotrienols in bone protection: Evidence from preclinical studies. eFood 1(3): 217-225.

Mitchell, S.J., Scheibye-Knudsen, M., Longo, D.L. \& De Cabo, R. 2015. Animal models of aging research: Implications for human aging and age-related diseases. Annual Review of Animal Biosciences 3: 283-303. 
Nesaretnam, K. \& Meganathan, P. 2011. Tocotrienols: Inflammation and cancer. Annals of the New York Academy of Sciences 1229(1): 18-22.

Ng, M.H., Choo, Y.M., Ma, A.N., Chuah, C.H. \& Hashim, M.A. 2004. Separation of vitamin E (tocopherol, tocotrienol, and tocomonoenol) in palm oil. Lipids 39(10): 1031-1035.

Olshansky, S.J. 2018. From lifespan to healthspan. JAMA 320(13): 1323-1324.

Ramanathan, N., Tan, E., Loh, L.J., Soh, B.S. \& Yap, W.N. 2018. Tocotrienol is a cardioprotective agent against ageing-associated cardiovascular disease and its associated morbidities. Nutrition \& Metabolism 15: 6 .

Reitermayer, D., Kafka, T.A., Lenz, C.A. \& Vogel, R.F. 2018 Interrelation between tween and the membrane properties and high pressure tolerance of Lactobacillus plantarum. BMC Microbiology 18(1): 72.

Sadikan, M.Z., Nasir, N.A.A., Agarwal, R. \& Ismail, N.M. 2020. Protective effect of palm oil-derived tocotrienol-rich fraction against retinal neurodegenerative changes in rats with streptozotocin-induced diabetic retinopathy. Biomolecules 10(4): 556.

Saw, T.Y., Malik, N.A., Lim, K.P., Teo, C.W.L., Wong, E.S.M., Kong, S.C., Fong, C.W., Petkov, J. \& Yap, W.N. 2019. Oral supplementation of tocotrienol-rich fraction alleviates severity of ulcerative colitis in mice. Journal of Nutritional Science and Vitaminology 65(4): 318-327.

Sen, C.K., Rink, C. \& Khanna, S. 2010. Palm oil-derived natural vitamin $\mathrm{E} \alpha$-tocotrienol in brain health and disease. Journal of the American College of Nutrition 29(sup3): 314S-323S.
Sen, C.K., Khanna, S. \& Roy, S. 2006. Tocotrienols: Vitamin E beyond tocopherols. Life Sciences 78(18): 2088-2098.

Sen, C.K., Khanna, S. \& Roy, S. 2004. Tocotrienol: The natural vitamin E to defend the nervous system? Annals of the New York Academy of Sciences 1031: 127-142.

Shen, C.L., Kaur, G., Wanders, D., Sharma, S., Tomison, M.D., Ramalingam, L., Chung, E., Moustaid-Moussa, N., Mo, H. \& Dufour, J.M. 2018. Annatto-extracted tocotrienols improve glucose homeostasis and bone properties in highfat diet-induced type 2 diabetic mice by decreasing the inflammatory response. Scientific Reports 8(1): 1-10.

Stiernagle, T. 2006. Maintenance of C. elegans (February 11, 2006), WormBook, ed. The C. elegans Research Community, WormBook. doi/10.1895/wormbook.1.101.1

Xun, C., Mamat, M., Guo, H., Mamati, P., Sheng, J., Zhang, J., Xu, T., Liang, W., Cao, R. \& Sheng, W. 2017. Tocotrienol alleviates inflammation and oxidative stress in a rat model of spinal cord injury via suppression of transforming growth factor- $\beta$. Experimental and Therapeutic Medicine 14(1): 431-438.

Department of Biochemistry

Universiti Kebangsaan Malaysia Medical Centre

Jalan Yaacob Latif, Bandar Tun Razak

56000 Cheras, Kuala Lumpur, Federal Territory

Malaysia

*Corresponding author; email: joaan@ukm.edu.my

Received: 12 June 2020

Accepted: 3 August 2020 